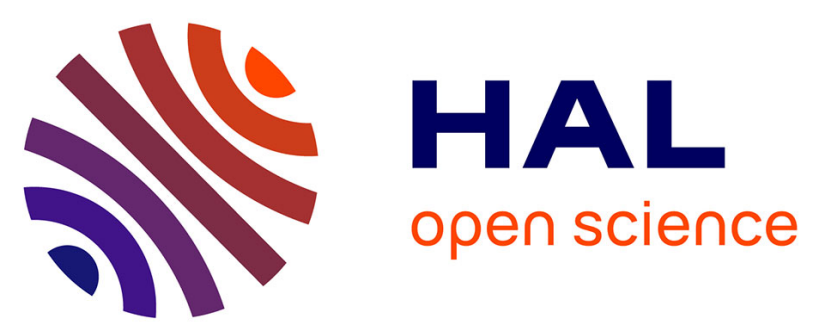

\title{
RAMAN SPECTROSCOPY CHARACTERIZATION OF POLYCRYSTALLINE GaP THIN FILMS GROWN BY MO-CVD PROCESS USING [Et2Ga - PEt2]3 AS ONLY SOURCE
}

F. Maury, M. Combes, G. Constant, Robert Carles, J. Renucci

\section{To cite this version:}

F. Maury, M. Combes, G. Constant, Robert Carles, J. Renucci. RAMAN SPECTROSCOPY CHARACTERIZATION OF POLYCRYSTALLINE GaP THIN FILMS GROWN BY MO-CVD PROCESS USING [Et2Ga - PEt2]3 AS ONLY SOURCE. Journal de Physique Colloques, 1982, 43 (C1), pp.C1347-C1-352. 10.1051/jphyscol:1982146 . jpa-00221803

\section{HAL Id: jpa-00221803 https://hal.science/jpa-00221803}

Submitted on 1 Jan 1982

HAL is a multi-disciplinary open access archive for the deposit and dissemination of scientific research documents, whether they are published or not. The documents may come from teaching and research institutions in France or abroad, or from public or private research centers.
L'archive ouverte pluridisciplinaire HAL, est destinée au dépôt et à la diffusion de documents scientifiques de niveau recherche, publiés ou non, émanant des établissements d'enseignement et de recherche français ou étrangers, des laboratoires publics ou privés. 


\title{
RAMAN SPECTROSCOPY CHARACTERIZATION OF POLYCRYSTALLINE GAP THIN FILMS GROWN BY MO-CVD PROCESS USING $\left[E t_{2} \mathrm{Ga}-P E t_{2}\right] 3$ AS ONLY SOURCE
}

\author{
F. Maury, M. Combes, G. Constant, R. Carles* and J.B. Renucci* \\ Laboratoire de cristallochimie, réactivité et protection des matériaux, \\ ERA 263, ENSCT 118 route de Narbonne, 31077 Toulouse Cedex, France \\ * Laboratoire de Physique des Solides, LA 74, Université P. Sabatier, \\ 118 route de Narbonne, 31062 Toulouse Cedex, France
}

\begin{abstract}
Résumé. - La croissance de couches minces polycristallines de GaP a été obtenue entre 650 et $775^{\circ} \mathrm{C}$ par dépôt chimique en phase vapeur, sous pression réduite, en utilisant comme source d'élément la seule molêcule organométa1lique $\left[\mathrm{Et}_{2} \mathrm{Ga} \mathrm{PEt}{ }_{2}\right]_{3}$. Le désordre de ces couches a été caractérisé par spectroscopie Raman.
\end{abstract}

Abstract. - Growth of polycrystalline GaP layers has been obtained between 650 and $775^{\circ} \mathrm{C}$, by low pressure metalorganic chemical vapor deposition, using the only molecule $\left[\mathrm{Et}_{2} \mathrm{Ga}-\mathrm{PE}_{2}\right]_{3}$ as element source. The disorder has been

characterized by Raman spectroscopy.

Introduction.- The metalorganic chemical vapor deposition process (MO-CVD) is well adapted to the realization of III-V semiconductor thin layers used in modern electronic devices[1]. The low cost solar cells fabrication increases the interest of III-V polycrystalline films. Consequently, the growth and properties of these semiconductor materials are intensively studied and in particular, new reactives are investigated for their elaboration.

Since the conventional organometallic compounds used in MO-CVD process are very reactive $\left(\mathrm{GaMe}_{3}, \mathrm{InEt}_{3}\right.$ ) and highly toxic $\left(\mathrm{AsH}_{3}, \mathrm{PH}_{3}\right)$, we have recently proposed the use of new organometallic compounds[2]. These molecules are $C 1 R_{2} G a \cdot M^{V} R^{\prime}{ }_{3}\left(M^{V}=A s, P\right.$; $\left.R, R^{\prime}=M e, E t\right)$ and the $M^{v}$ atom is already linked to the Ga atom by a donor-acceptor bond. In a similar way, we have investigated original starting materials, sufficiently stable and volatil to give $\simeq 10^{-4}$ mole fraction in the gas stream, with a more energetic bond between the III and $V$ element. We have prepared the trimer molecule $\left[\mathrm{Et}_{2} \mathrm{Ga}-\mathrm{PEt}_{2}\right]_{3}$ which presents energetic covalent bonds $\mathrm{Ga}-\mathrm{P}$ and the ordered cyclic chain[Ga-P] 3 . The mass spectra analysis has revealed the solidity of this chain, then, it is possible that this sequence may survive long enough to be incorporated into the film growth without an external source of element.

This paper reports results on polycrystalline GaP film growth by MO-CVD using this molecule $\left[\mathrm{Et}{ }_{2} \mathrm{Ga}_{\mathrm{PEt}}\right]_{3}$ which have been characterized by SEM, reflection electron diffraction, EDAX and Raman spectroscopy. The results obtained by this last technic will be developped in a distinct paragraph.

Experimenta1.- The complex between gallium triethyl and diethyl phosphine loses ethane smoothly above $100^{\circ} \mathrm{C}$ with quantitative formation of $\left[\mathrm{Et}_{2} \mathrm{Ga}-\mathrm{PEt} \mathrm{t}_{2}\right.$. After purification by recrystallization, we obtain a white crystalline compound which sublimates at $100-110^{\circ} \mathrm{C} / 0.05$ torr. This adduct is very stable in an inert water free atmosphere and easy to handle but its vapor pressure is very low. Under atmospheric pressure, this molecule is not carried in the gas stream; so, in order to obtain a sufficient mole fraction in the gas phase, the low pressure process has been used. 


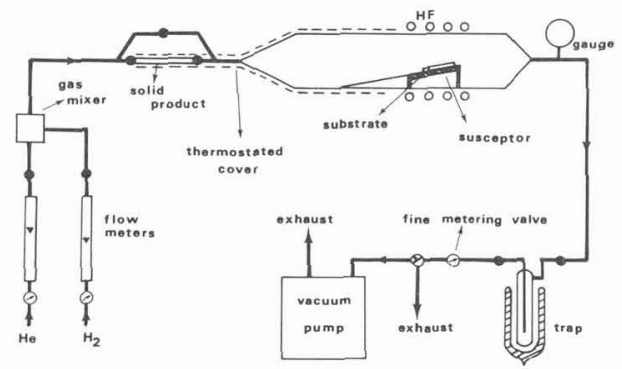

Fig. 1 - Sketch of the low pressure growth apparatus.

( Schéma de 1'appareillage de dépôt)

The growth apparatus is an horizontal reactor made up of a quartz tube of $5 \mathrm{~cm}$ ID and $30 \mathrm{~cm}$ length, containing a graphite susceptor coated with SiC and heated by HF induction (fig. 1). Deposition temperatures were measured with a thermocouple inserted into the susceptor. The carrier gas was purified helium and/or hydrogen which flow was monitored by a Brooks flow meter. Working pressure was adjusted by varying the flow of the pump using a fine metering valve. The solid product was introduced into a pyrex container, sublimated at $110^{\circ} \mathrm{C}$ and transported by the carrier gas to the substrates. After pyrolysis, the gas was trapped at liquid nitrogen temperature at the outlet of the reactor and analyzed by mass spectrometry. The deposition temperature, the nature and the flow of the carrier gas were changed in order to obtain the optimum growth conditions.

The $\mathrm{K} \alpha 1$ ines of $\mathrm{Ga}$ and $\mathrm{P}$ at $12.5 \mathrm{kV}$ were used for the EDAX analysis, only corrected for the background and compared with a single crystalline standard under the same experimental conditions.

The Raman measurements were performed in the backscattering geometry using the $4880 \AA$ line of an argon laser. The samples were kept inside the vacuum chamber of a cryostat in order to avoid scattering from air and to cool them at liquid nitrogen temperature. The collected light was dispersed by a triple spectrometer associated with conventional photon counting and monitored by a microcomputer.

Results and discussion.

- study of the growth - Polycrystalline GaP layers were obtained at $600^{\circ} \mathrm{C}$ when this molecule is sublimated at $150^{\circ} \mathrm{C} / 2 \cdot 10^{-4}$ torr without carrier gas. These films, constituted of whiskers partially covered by small grains (fig. 2), are very inhomogeneous probably because the partial pressure of the product was too weak and impossible to control. Then we have worked at a reduced carrier gas pressure of 100 torr in all the other experiments.

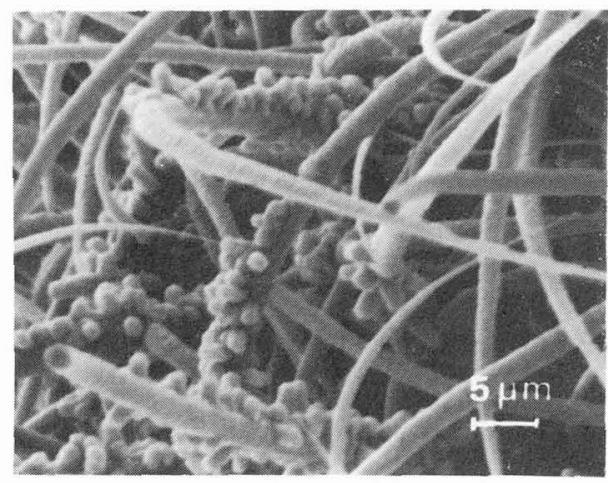

Fig. 2 - GaP whiskers obtained at $600^{\circ} \mathrm{C}$ in experiments realized without carrier gas.

( Trichites de GaP obtenues à $600^{\circ} \mathrm{C}$ dans des expériences réalisées sans gaz vecteur) 


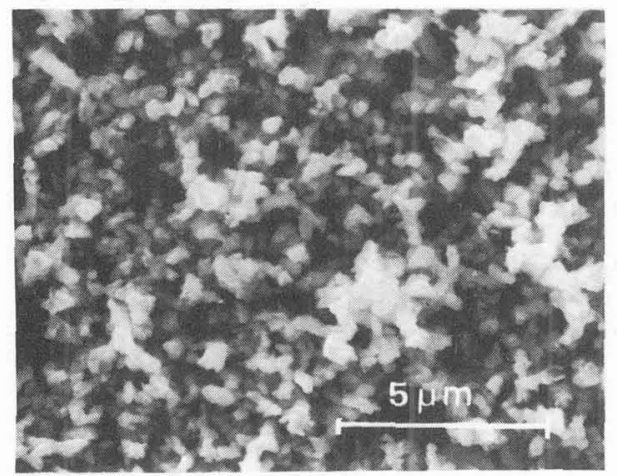

Fig. 3 - Typical small grains GaP film grown at $730^{\circ} \mathrm{C}$ on $(100) \mathrm{Si}$ with helium as carrier gas.

( Dépôt polycristallin de GaP obtenu à $730^{\circ} \mathrm{C}$ sur $\mathrm{Si}(100)$ avec 1 'hêlium comme gaz vecteur)

The substrates used in this study are single crystalline $(0001) \mathrm{Al}_{2} \mathrm{O}_{3},(100) \mathrm{Si}$, (111)Si and polycrystalline alumina. Whatever the deposition temperature, no morphological difference is clearly observed; in particular, with the single crystalline substrates, no obvious preferential orientation appears (fig. 3 and $4 \mathrm{~b}$ ).

The growth has been studied in a wide range of temperature $\left(550-800^{\circ} \mathrm{C}\right)$ with He flow between $10-301 / \mathrm{h}$. Alloy "droplets" $\mathrm{Ga}_{\mathrm{x} \mathrm{P}_{1-\mathrm{x}}}(\mathrm{x}>0.85)$ grow at $550^{\circ} \mathrm{C}$ and when the temperature increases unti $1625^{\circ} \mathrm{C}$, the ratio $\mathrm{Ga} / \mathrm{P}$ decreases from 5.7 to 1 . This fact can be correlated to the analysis of the mass spectra of decomposition gas which shows that the alkyl phosphines are totally pyrolysed above $625^{\circ} \mathrm{C}$.

At $650^{\circ} \mathrm{C}$ the deposits are constituted of GaP whiskers, $>10 \mu \mathrm{m}$ length, covered by sma11 grains, $\simeq 0.1 \mu \mathrm{m}$ (fig. $4 \mathrm{a}$ ). It is probable that this temperature is too low to give a good crystallization and two mechanisms can explain this growth: whiskers can be obtained by the V.L.S. (Vapor-Liquid-Solid) mechanism[3] since Ga droplets appear at low temperature, and grains may grow due to the pyrolysis of the molecule in the vapor phase [2]. From 700 to $775^{\circ} \mathrm{C}$ the films are homogeneous and characterized by small packed grains, $<0.3 \mu \mathrm{m}$ (fig. 3 and $4 \mathrm{~b}$ ). When the growth temperature increases, the grains are not much larger and above $800^{\circ} \mathrm{C}$ no deposit is obtained.

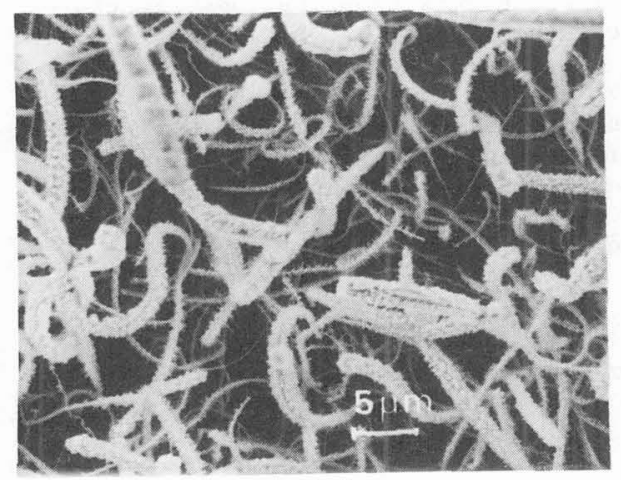

(a)

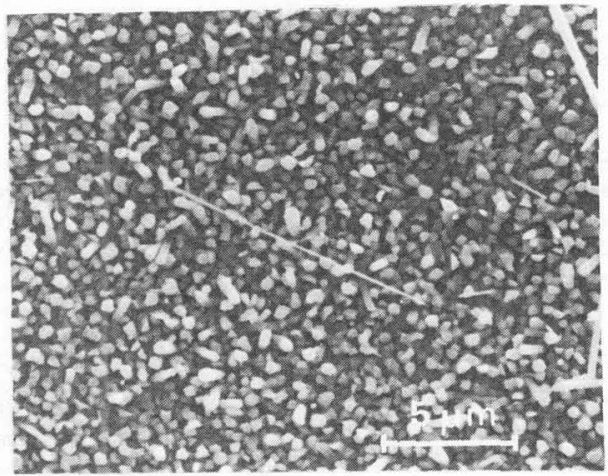

(b)

Fig. 4 - GaP layers obtained on $(0001) \mathrm{Al}_{2} \mathrm{O}_{3}$ with He as carrier gas, at $650^{\circ} \mathrm{C}$ (a) and at $700^{\circ} \mathrm{C}$ with a growth rate $<0.3 \mu / \mathrm{h}$ (b).

( Dépôt de GaP obtenu sur $\mathrm{Al}_{2} \mathrm{O}_{3}(0001)$ avec l'hêlium comme gaz vecteur, à $650^{\circ} \mathrm{C}$ (a) et à $700^{\circ} \mathrm{C}$ avec une vitesse de croissance $\left.<0.3 \mu / \mathrm{h}(\mathrm{b})\right)$. 


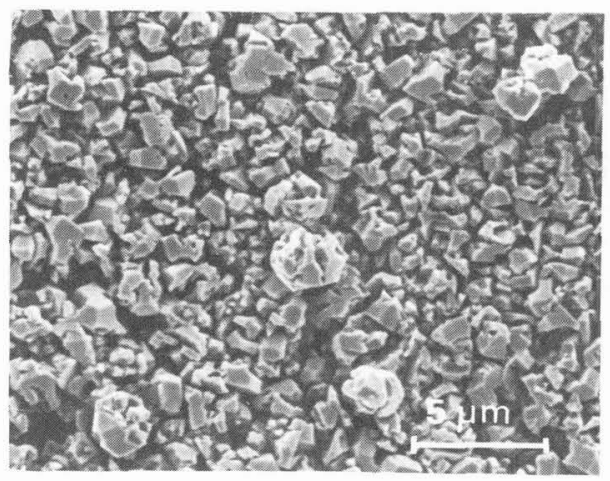

Fig. 5 - Typical GaP layer obtained at $700^{\circ} \mathrm{C}$ with hydrogen as carrier gas, the growth rate $=1 \mu \mathrm{m} / \mathrm{h}$.

( Dépôt polycristaliin de GaP obtenu à $700^{\circ} \mathrm{C}$ avec 1 'hydrogène comme gaz vecteur, la vitesse de croissance $=1 \mu \mathrm{m} / \mathrm{h}$ )

Experiments realized at $700^{\circ} \mathrm{C}$ with a mixture of helium and hydrogen as carrier gas show that hydrogen favorizes the decomposition of this bulky molecule probably making easier the alkyl radical elimination. The nature and the growth rate $(1 \mu \mathrm{m} / \mathrm{h})$ of these films are the same for all the substrates and seem independant of hydrogen flow $(1-29 \mathrm{l} / \mathrm{h})$. Grains with $\mathrm{l} \mu \mathrm{m}$ average dimension are obtained in one hour but reflection electron diffraction patterns show no evidence of preferential orientation (fig. 5).

- Raman characterization of the layers - Lattice vibrations are very sensitive to the nearest neighbourhood and, therefore, probe the crystal structure and quality on an extremely small scale of the order of the lattice spacing. As a consequence, Raman spectroscopy can be used as a versatile tool for local characterization of thin films in a non destructive way.

Our main purpose, here, is to probe the crystallinity of films. This is achieved through the comparison of the Raman spectra of the films to that of a high purity single crystal recorded under the same experimental conditions.

We present in fig. 6 and 7 the spectra of a single crystal of GaP, in the first order optical scattering range and over a wider range respectively, and those of layers of GaP obtained for different deposition temperatures. Besides structures already present in the spectra of the single crystal several others appear in that of the layers.

These features were already found in Raman spectra of single crystal of III-V compounds which surfaces were mechanically perturbated [4] or in that of their alloys[5]. They were interpreted as disorder activated first order Raman scattering (DAFORS) and reflect the breakdown of the $\vec{k}=\vec{b}$ selection rule due to the lack of translationnal symmetry. Therefore their intensities give a measure of the order present in the sample.

We first analyze the DAFORS in the optical first order scattering region (fig. 6). The two peaks at $367 \mathrm{~cm}^{-1}$ and $403 \mathrm{~cm}^{-1}$, present in all the spectra, correspond to the $T O(\Gamma)$ and $L O(\Gamma)$ characteristic of crystalline GaP [6]. However one observes in fig. 6b.c.d.e a high asymmetry of the low frequency tails of these peaks. This give evidence of optical disorder activated scattering. The corresponding bands are labelled D.A.T.O. and D.A.L.O. [5]. Their location on the low energy side is compatible with the shape of the dispersion curves in GaP [7] where the frequencies of the optical branches decrease away from the center of the zone. The degree of asymmetry of the TO( $\Gamma)$ and $L O(\Gamma)$ probes therefore the presence of disorder. From that point of view it appears that best choice for the growth temperature lies around $700^{\circ} \mathrm{C}$. The influence of the nature of the substrate and that of the carrier gas have been investigated in a similar way. For $700^{\circ} \mathrm{C}$ no clear influence on the degree of crystallinity has been detected.

The same conclusion can be drawn from the analysis of the DAFORS in the acous- 


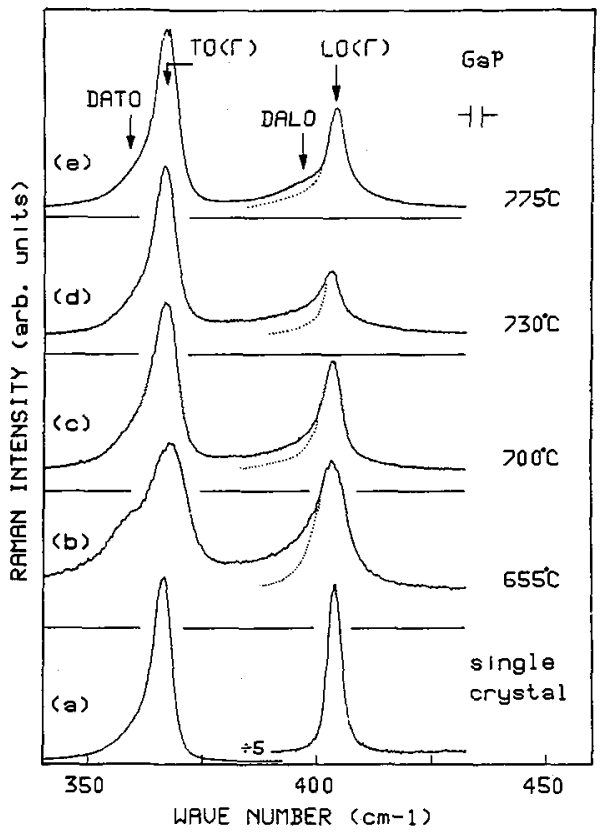

Fig. 6 - First order optical Raman spectra recorded at $300 \mathrm{~K}$ for: (a) GaP single crystal, (b-e) GaP films obtained at different growth temperatures. Dotted lines are guide for the eyes to show the asymmetry of the LO $(\Gamma)$ peaks.

(Spectres Raman du le ordre optique enregistrés à $300 \mathrm{~K}$ pour: (a) un monocristal de $\mathrm{GaP},(b-e)$ des films de GaP obtenus à différentes températures de croissance. Des pointillés ont été portés pour montrer l'asymétrie des pics LO $(\Gamma)$.

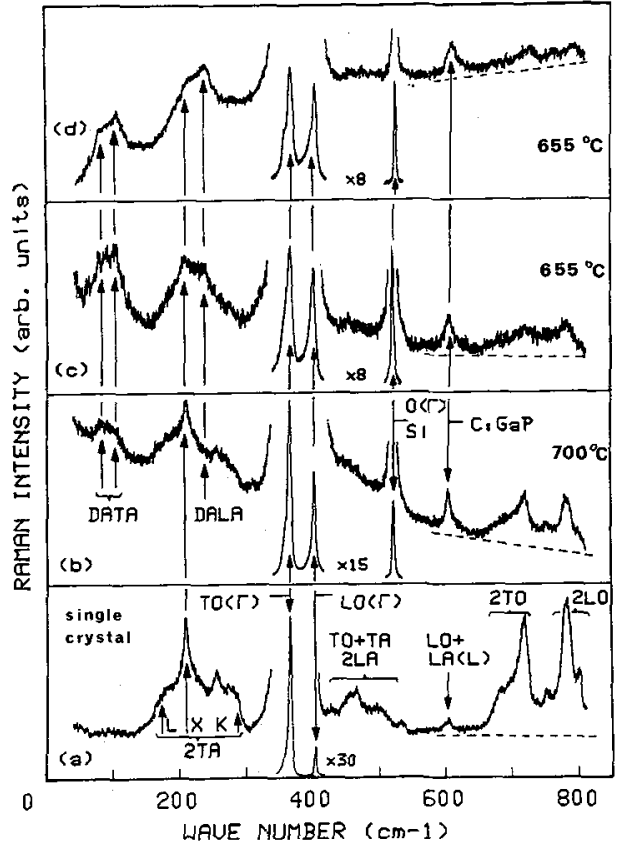

Fig. 7 - Raman spectra of: GaP single crystal (a) and of $\mathrm{GaP}$ thin layers grown by MO-CVD at $700^{\circ} \mathrm{C}$ (b) and $655^{\circ} \mathrm{C}$ (c and d). They are recorded at $300 \mathrm{~K}$ $(a-c)$ or at $77 \mathrm{~K}$ (d).

(Spectres Raman d'un monocristal de GaP (a) et de couches polycristallines de GaP obtenues par MO-CVD à une température de croissance de $700^{\circ} \mathrm{C}$ (b) et de $655^{\circ} \mathrm{C}$ ( $c$ et $\left.d\right)$. Ils ont été enregistrés à $300 \mathrm{~K}(\mathrm{a}-\mathrm{c})$ ou à $77 \mathrm{~K}(\mathrm{~d})$.

tical region between $50 \mathrm{~cm}^{-1}$ and $300 \mathrm{~cm}^{-1}$ (fig. 7). Here two new bands due also to first order activated processes appear in the Raman spectra of the layers (fig. $7 \mathrm{bcd}$ ) and are labelled D.A.T.A. and D.A.L.A. [4]. As exemplified in fig. 7c and $7 d$ they correspond to first order processes since they are less muffled than the second order scattering $(2 \mathrm{TA}(\mathrm{X})$ ) when the temperature decreases from $300 \mathrm{~K}$ (fig. 7c) to $77 \mathrm{~K}$

(fig. 7d). The ratio of the intensities of these bands over that of the "crystalline" 2TA one gives also a measure of the disorder. This ratio increases from fig. $7 \mathrm{~b}$ to fig. $7 \mathrm{c}$ confirming that the best growth conditions correspond to $700^{\circ} \mathrm{C}$.

An other important point must be stressed. The peak located at $610 \mathrm{~cm}^{-1}$ (fig. $7 b-7 d$ ), lying between the first order optical scattering of the Si substrate $\left(O(\Gamma)\right.$ at $\left.520 \mathrm{~cm}^{-1}\right)$ and the second order optical modes of Gap $\left(660-800 \mathrm{~cm}^{-1}\right)$, has a typical first order behavior (fig. 7c-7d). Thus, although its frequency corresponds to that of the LO + LA(L) band of crystalline GaP (fig. 7a) we assign it to the local 
mode of carbon in GaP [6]. This is supported by its relatively high intensity (see fig. $7 \mathrm{a}$ and $7 \mathrm{~b}$ ).

The intensity of this peak which is larger in fig. 7c than in fig. $7 \mathrm{~b}$ (compare for exemple its intensity to that of the TO(T) or LO(T) of $\mathrm{GaP}$ ) follows the degree of disorder. So the substitution of $\mathrm{C}$ in $\mathrm{GaP}$ during the growing process could be implied in the origin of the microscopic disorder revealed by this Raman experiments.

We wish to thank THOMSON C.S.F., Orsay France, for their financial support to one of us.

\section{References.}

[1] MOROSANU C.E., Proc. of the 8th Internat. Conf. on CVD, Blocher J.M., vuillard G.E. and wahl G., Ed. J. Electrochem. Soc., (1981) 403.

[2] ZAOUR A., SALVETAT E., SAKAYA J., MAURY F. and CONSTANT G., J. Crystal Growth $55(1981) 135$.

[3] KaSAhara J., KAJIWARA K. and YAMADA T., J. Crystal Growth, 38 (1977) 23.

[4] CARLES R., SAINT-CRICQ N., ZWICK A., RENUCCI M.A. and RENUCCT J.B., J. Phys. Soc. Japan 49 (1980) suppl. A, 665.

[5] SAINT-CRICQ N., CARLES R., RENUCCI J.B., ZWICK A. and RENUCCI M.A., Solid State Commun. 39 (1981) 1137 .

[6] HOFF R.M. and IRWIN J.C., Can. J. Phys. 51 (1973) 63.

[7] BORChERDS P.H., KUNC K., ALFREY G.F. and HALL R.L., J. Phys. C: Solid State Phys. 12 (1979) 4699. 